\title{
Synthesis and Characterization of Polyvinyl alcohol/Silver Nanocomposite films and Effect of Gamma Radiation
}

\author{
M.G. Pushpanjali ${ }^{1}$, H.M. Somashekarappa ${ }^{2 *}$ \\ ${ }^{1,2}$ Centre for Application of Radioisotopes and Radiation Technology (CAART), Mangalore University, Mangalore-574199, \\ Karnataka, India \\ "Corresponding author Email: carrtmu@gmail.com
}

Available online at: www.isroset.org

Received: 24/Jan/2019, Accepted: 12/Feb/2019, Online: 28/Feb/2019

\begin{abstract}
In this work, a unique nanocomposite film based on poly (vinyl alcohol)/silver (PVA/Ag) has been synthesized using solution casting technique and the samples were exposed to gamma radiation for different doses $0,25,50$ and $75 \mathrm{kGy}$. Ultraviolet-Visible spectroscopy, the characteristic Surface Plasmon Resonance (SPR) band placed at around $427 \mathrm{~nm}$. FTIR analysis shows the formation of chemical bonding/conjugation between the $\mathrm{Ag}$ nanoparticles and PVA chains. X-ray diffraction analysis shows that $\mathrm{Ag}$ metal is present in face-centered cubic (fcc) crystal structure. The morphology of particles was studied using Field Emission Scanning Electron Microscopy (FESEM) it shows the nanoparticles are in spherical shape. The presence of Ag was confirmed using Energy Dispersive X-ray Spectroscopy (EDX) elemental analysis. Transmission Electron Microscopy (TEM) shows the particles were nano size and monodispersed. The antibacterial activities of the PVA/Ag nanocomposites were obtained using the zone inhibition method. The samples were tested against Gram-positive bacteria: Bacillus Subtilis, Staphylococcus aureus, and Gram-negative bacteria: Escherichia coli, Klebsiella pneumoniae. This study reveals that the irradiated PVA/Ag nanocomposites film shows good antibacterial activity against the Gram-positive and Gramnegative bacteria.
\end{abstract}

Keywords -- Poly (vinyl alcohol)/Silver Nanocomposites, Gamma Radiation, Characterization, Antibacterial property.

\section{INTRODUCTION}

The synthesis of nanoparticles has created unique attention because of modified structure and increased activity compared to macro and micromolecules. Nanocomposites are multiphase materials with one of their dimension between 1 to $100 \mathrm{~nm}$ in size [1-2]. It has physical and mechanical properties including high strength, hardness, and heat resistance. Gamma irradiation offers several advantages for the preparation of metal-nanoparticles [3]. A large number of hydrated electrons produced during $\gamma$-irradiation can decrease the metal ions to zero valiant metal particles. A chart made by many authors suggested that irradiation cause a chemical change in polymers, including cross-linking and chain scission [4]. Silver nitrate is a rapid conducting ion in a number of crystalline and amorphous materials; its incorporation within a polymeric system may be supposed to enhance its antibacterial property. Polymeric nanocomposites are enhanced composites obtained from nanoparticles and a polymeric matrix. Because of the chemical character, shape, and unique structure of polymers, nanoparticles can be distributed in a polymer matrix in the modified shapes [5-6]. In general, nanocomposites based on organic polymers have various advantages such as long-term stability, good processability and electronic, catalytic, optical and magnetic properties [7]. Therefore nanocomposites could potentially give many applications in various areas such as optoelectronics, automotive, aerospace, etc... Ag nanoparticles are effective against many bacteria, it can also kill the different types of virus and fungi due to an enhancement of antibacterial, antivirus, and antifungal activity of $\mathrm{Ag}$ at the nanoscale. The antibacterial activities of Ag/PVA nanocomposites were obtained using the zone inhibition method [8-9]. The samples were tested against Gram-positive bacteria: Bacillus Subtilis, Staphylococcus aureus, and Gram-negative bacteria: Escherichia coli, Klebsiella pneumoniae.

The aim of this study is to synthesize PVA/Ag nanocomposite films using solution casting technique and find out the effect of gamma radiation. Irradiated samples were characterized using different methods such as UV, XRD, FTIR, FE-SEM, EDAX, and TEM. PVA/Ag samples were tested against gram-positive and gram-negative bacteria. This shows a high zone inhibition and good antibacterial property. 


\section{MATERIALS AND EXPERIMENTAL METHODS}

\section{A. Materials}

Silver Nitrate (AgNO3) (M.wt. $=169.87$ g/mol; 99\% hydrolyzed) was obtained from Merck. Poly (vinyl alcohol) $($ PVA M.wt $=30,000 \mathrm{~g} / \mathrm{mol})$. All chemicals were used without further purification.

\section{B. Preparation of PVA/Ag Nanocomposites}

Poly (vinyl alcohol) films were synthesized using solution casting technique. PVA solution was prepared by dissolving $5 \mathrm{gm}$ in $100 \mathrm{ml}$ of distilled water. Then warmed at $70^{\circ} \mathrm{C}$ and thoroughly stirred until the polymer becomes completely soluble. After $10 \mathrm{ml}$ of freshly prepared different concentration of silver nitrate solution (0.01 M-0.1 M) was added to the above PVA solution with continuous stirring for 3 hours (in dark room) [10]. Finally, the solution was cast onto a petri plate. The homogenous film was obtained after drying at room temperature for 8-10 days. All the films were exposed to gamma radiation with a dose range of 0,25 , 50 and 75 kGy using Cobalt-60 (GC 5000; BRIT, Mumbai).

\section{Characterization Techniques}

Optical characterization of PVA/Ag nanocomposite films was measured using Ultraviolet-Visible (UV/VIS) spectroscopy (Shimadzu, UV-1800) in the wavelength range 190 to $800 \mathrm{~nm}$. X-Ray Diffraction (XRD) (Rigaku Miniflex) was used to determine the diffraction patterns of the crystal structure and the measurements were recorded over a diffraction angle (2 $\theta)$ range set between $10^{\circ}$ to $90^{\circ}$ degrees. Transmission Electron Microscope (TEM) (Jeol/JEM 2100) was used to study the shape of particles and to determine the size distribution of the nanoparticles. Fourier Transformation of Infrared Spectroscopy (FTIR) is to find the nature of bond formation in PVA/Ag films. The surface morphology of the studied nanocomposites was examined using Field Emission Scanning Electron Microscopy (FESEM) (ULTRA 55 FESEM, Karl Zeiss). The presence of Ag was confirmed by the Energy Dispersive X-ray Spectroscopy (EDX) elemental analysis.

\section{RESULTS AND DISCUSSION}

Figure 1, shows the prepared nanocomposites film of PVA/Ag at different gamma radiation doses, in which the white color of the film has been changed to yellow, golden and dark golden following the radiation steps up to $75 \mathrm{kGy}$. The color change of the film shows various reduction stages of silver ions by irradiation. It confirms the formation of silver nanoparticles in the PVA matrix.

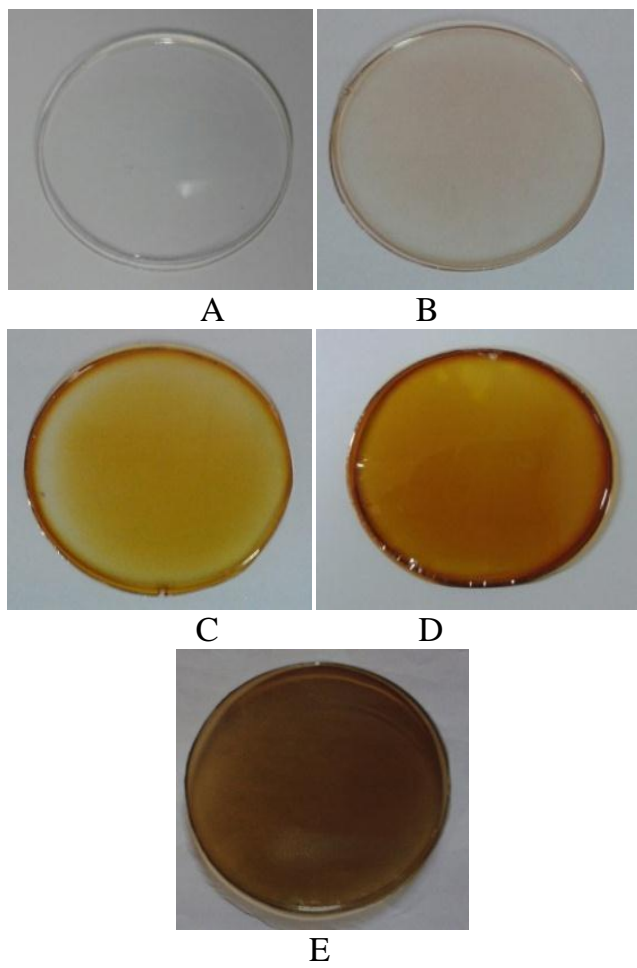

Figure 1, Shows the (a) Pure PVA and (b) PVA/Ag (c-e) Irradiated PVA/Ag (doses of 25-75 kGy)

\section{A. UV-VIS Spectral Studies}

Figure 2, shows the UV/VIS spectra of Ag/PVA nanocomposite films containing different molar concentrations of silver nitrate. The characteristic peak of the silver nanoparticles for different molar concentration of silver nitrate $(0.01 \mathrm{M}-0.1 \mathrm{M})$ appears in the range of 427 $\mathrm{nm}$ to $441 \mathrm{~nm}$. With increasing the molar concentration, the peak gradually increased and slightly shift was observed. The absorbance of the silver nanoparticles increased with increasing silver concentration, indicating that more silver nanoparticles were created [11]. The slight shift of the peak maximum to longer wavelengths implies that the average sizes of the silver nanoparticles slightly increased with increasing the molar concentration.

Figure (3-5), shows the UV/Vis absorption spectra of unirradiated and irradiated PVA/Ag nanocomposite films. In figure 3 , shows a reduction in the absorbance of the band at higher irradiation dose $(75 \mathrm{kGy})$ may be understood as follows at higher irradiation doses, gamma irradiation induces chain scissions in the polymer matrix. Thus, the polymer chains acquired mobility along with the period of experiment scale. As polymer chains relax, stresses are released. This causes silver nanoparticles to move again, allowing crystals to aggregate which in turn reduces the absorbance and increases wavelength. In Figure. 4, shows the absorption peak at $421 \mathrm{~nm}$ for irradiated Ag/PVA nanocomposite film $(0.05 \mathrm{M})$ was increased with increasing 
irradiation dose indicating the formation of silver nanoparticles. The increase of absorbance with increasing irradiation dose indicates the increase of silver nanoparticle content i.e. more decrease of $\mathrm{Ag}^{+}$to $\mathrm{Ag}^{\mathrm{o}}$ nanoparticles. It was noticed that the peak gets narrower, sharper and also gradually increases in the absorbance with increasing either irradiation dose. In Figure 5, shows, as the irradiation dose increased (25-75 kGy), the peak is shifted from $428 \mathrm{~nm}$ to $422 \mathrm{~nm}$ indicating the formation of smaller metal nanoparticles.

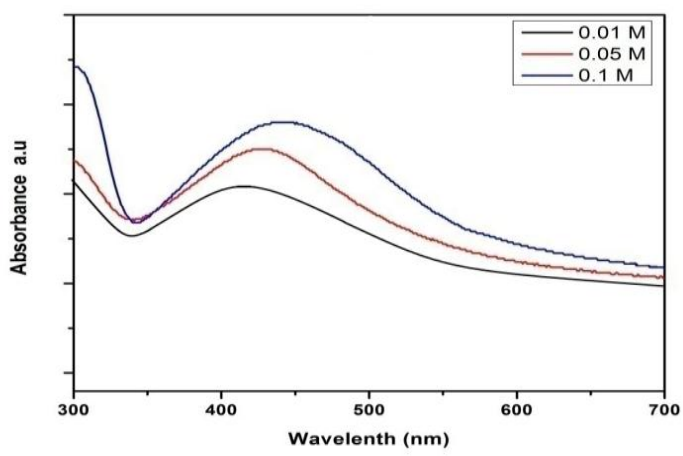

Figure 2, UV/Vis spectra of PVA/Ag nanocomposite films containing different concentrations of $\mathrm{AgNO}_{3}$

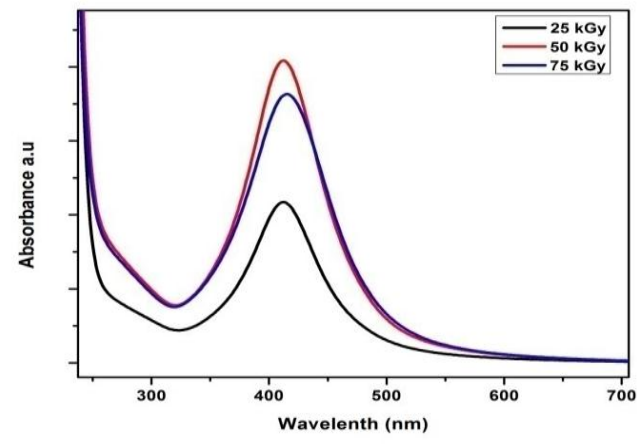

Figure 3, UV/Vis spectra of PVA/Ag nanocomposite films $(0.01 \mathrm{M}$ $\mathrm{AgNO}_{3}$ ), Gamma irradiated to different doses

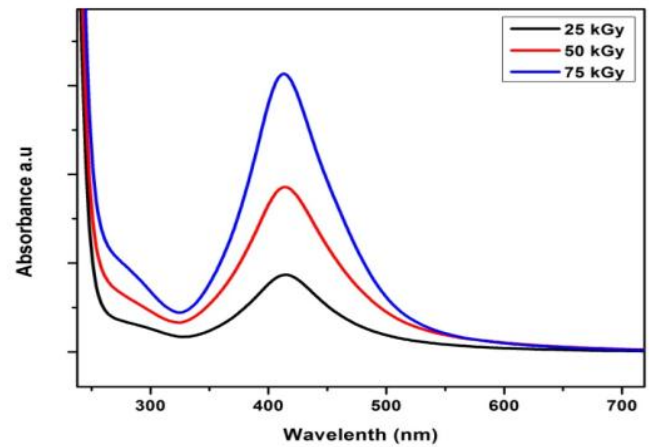

Figure 4, UV/Vis spectra of PVA/Ag nanocomposite films $(0.05 \mathrm{M}$ $\mathrm{AgNO}_{3}$ ), Irradiated to different doses

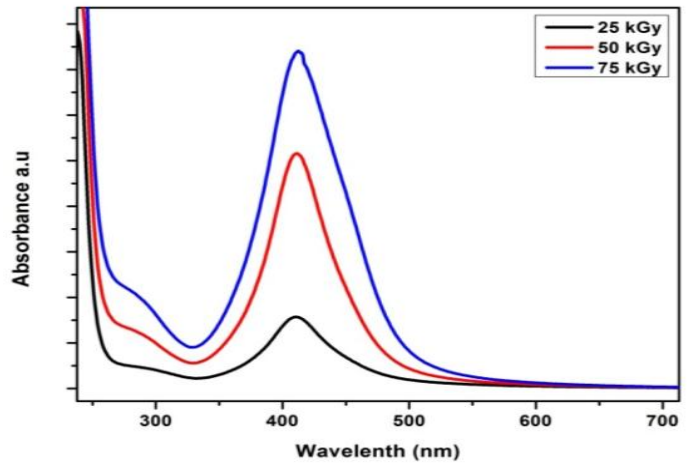

Figure 5, UV/Vis spectra of PVA/Ag nanocomposite films $(0.1 \mathrm{M}$ $\mathrm{AgNO}_{3}$ ), Gamma irradiated to different doses

\section{Estimation of silver nanoparticles size:}

Consider that silver nanoparticles have spherical shape, Mie theory [12] was applied for the estimation of silver nanoparticles size in PVA/Ag nanocomposite. Relationship between SPR peak position and particle size experimentally established by Evanoff and Chumnov [13] was used for the calculation of silver nanoparticles in PVA/Ag films using experimental data:

$$
\mathrm{D}=0.715 \lambda_{\max }-258
$$

Where $\mathrm{D}=$ Particle diameter $(\mathrm{nm}), \lambda_{\max }$ is the SPR peak place in UV-VIS absorbance spectrum. The calculated silver nanoparticles size was listed in Table (1).

Table 1, Determination of the particle size from UV/Vis spectroscopic data

\begin{tabular}{|c|c|c|c|c|}
\hline $\begin{array}{c}\text { PVA } \\
\%\end{array}$ & $\begin{array}{l}\mathrm{AgNO}_{3} \\
\text { conc. } \\
(\mathrm{M}) \\
\end{array}$ & $\begin{array}{c}\text { Irradiation } \\
\text { dose }(k G y)\end{array}$ & $\begin{array}{l}\lambda_{\max } \\
(\mathbf{n m})\end{array}$ & $\begin{array}{c}\text { Particle } \\
\text { diameter D } \\
(\mathbf{n m})\end{array}$ \\
\hline \multirow{12}{*}{$5 \%$} & \multirow{4}{*}{$1 \times 10-2$} & 0 & 427 & 47.31 \\
\hline & & 25 & 415 & 38.73 \\
\hline & & 50 & 416 & 39.44 \\
\hline & & 75 & 413 & 37.29 \\
\hline & \multirow{4}{*}{$5 \times 10^{-2}$} & 0 & 434 & 52.31 \\
\hline & & 25 & 421 & 43.06 \\
\hline & & 50 & 418 & 40.87 \\
\hline & & 75 & 414 & 38.01 \\
\hline & \multirow{4}{*}{$1 \times 10^{-1}$} & 0 & 441 & 57.36 \\
\hline & & 25 & 428 & 48.02 \\
\hline & & 50 & 425 & 45.87 \\
\hline & & 75 & 422 & 43.73 \\
\hline
\end{tabular}

\section{B. X-Ray Diffraction Studies}

In figure (6-7), shows the XRD patterns of pure PVA and irradiated PVA/Ag nanocomposite films containing $0.01 \mathrm{M}$ concentration of $\mathrm{AgNO}_{3}$. In figure 6, the XRD pattern of pure PVA exhibits strong and broad diffraction peak located at $2 \theta=19.710$. The diffraction peak at $2 \theta=19.71^{\circ}$ corresponds to the (110) reflection, a plane which contains 
the extended planar zigzag chain direction of the crystallites. This peak has resulted from the part crystallinity in the PVA matrix. This crystallinity is a result of strong intermolecular and intramolecular hydrogen bonding between the PVA molecular chains. In Figure.7, Irradiated PVA/Ag nanocomposites shows four new diffraction peaks at $2 \theta=$ $38.29^{\circ}, 44.51^{\circ}, 64.72^{\circ}$ and $77.45^{\circ}$. These peaks can be indexed to the planes (111), (200), (220) and (311); respectively disclosing that the Ag nanoparticles are formed in the PVA matrix and their crystal structure is face center cubic (FCC) structure according to JCPDS (No.4-0783). This is a confirmation of spontaneous reduction of $\mathrm{Ag}^{+}$ion to $\mathrm{Ag}^{\mathrm{O}}$ nanoparticles in the metallic form using irradiation. As the irradiation dose was increased from 25 to $75 \mathrm{kGy}$, the intensity of the Ag lines decreases [14]. Also, it can be seen that the prepared growth plane of the Ag nanoparticles is the (111) lattice plane which shows the highest intensity all over the diffraction pattern. At higher irradiation dose (75 kGy), the $\mathrm{Ag}$ lines were increased again due to the particles growth. The intensity of the PVA line at $2 \theta=19.71^{\circ}$ was decreased with increasing irradiation dose, indicating that the crystallinity is slightly weakened.

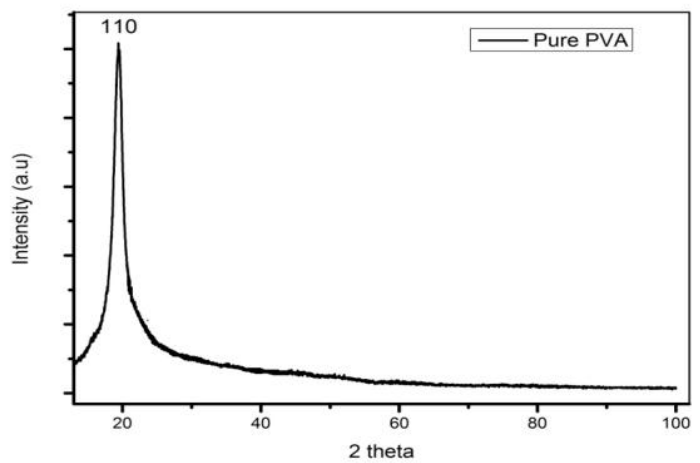

Figure 6, XRD patterns of pure PVA

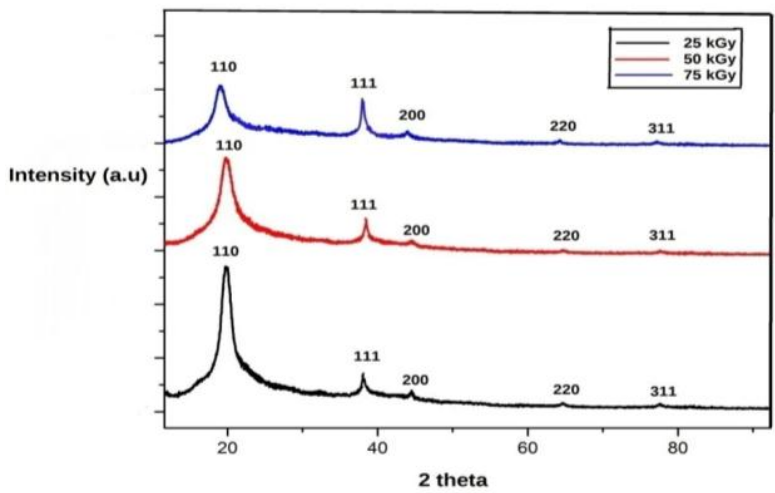

Figure 7, XRD patterns of PVA/Ag nanocomposite films $(0.05 \mathrm{M}$ $\mathrm{AgNO}_{3}$ ),

Gamma irradiated at various irradiation doses.

Where, $\lambda$ is the wavelength $(\lambda=0.154 \mathrm{~nm}), \mathrm{K}$ is a constant equals $0.9, \theta$ is the angle of deviation of the diffraction beam. $\beta$ is FWHM of the peak corresponding to a plane ( 111 reflection) and $\theta$ is the diffraction angle obtained from
$2 \theta$ values corresponding to maximum intensity peak in XRD pattern. Table 2 shows the particle size ' $D$ ' was calculated based on the regular broadening of XRD peaks as a function of decreasing crystallite size [15]. This broadening is a fundamental property of XRD described by well-established Scherer theory:

$$
\mathrm{D}=\frac{\mathrm{K} \lambda}{\beta \cos \theta}
$$

Table 2, The calculated values of crystalline particle size (D, nm)

\begin{tabular}{|c|c|c|c|}
\hline $\begin{array}{c}\text { PVA } \\
\text { \% }\end{array}$ & $\begin{array}{c}\text { AgNO } \\
\text { Conc. }(\mathbf{M})\end{array}$ & $\begin{array}{c}\text { Irradiation } \\
\text { dose (kGy) }\end{array}$ & $\begin{array}{c}\text { Particle size } \\
\mathbf{D} \text { (nm) }\end{array}$ \\
\hline \multirow{2}{*}{$5 \%$} & \multirow{2}{*}{$1 \times 10^{-2} \mathrm{M}$} & 25 & 18.45 \\
\cline { 3 - 4 } & & 50 & 16.77 \\
\cline { 3 - 4 } & & 75 & 15.81 \\
\hline
\end{tabular}

\section{FTIR studies}

Figure 8, represents the FTIR spectra of pure PVA and PVA/Ag nanocomposite films (with various concentration of $\mathrm{Ag}$ ) in the wavenumber range $500-4000 \mathrm{~cm}^{-1}$. In case of pure PVA, a strong band at $3276 \mathrm{~cm}^{-1}$ is assigned to $\mathrm{O}-\mathrm{H}$ stretching frequency indicating the presence of hydroxyl groups. The band observed at $2926 \mathrm{~cm}^{-1}$ correspond to $\mathrm{C}-\mathrm{H}$ stretching vibrations; respectively the absorption band at $1647 \mathrm{~cm}^{-1}$ arises due to $\mathrm{C}=\mathrm{C}$ stretching. The band at 1330 $\mathrm{cm}^{-1}$ is due to the coupling of $\mathrm{O}-\mathrm{H}$ plane vibration at 1410 $\mathrm{cm}^{-1}$ with $\mathrm{C}-\mathrm{H}$ wagging vibrations. The existence of broad bands in the region $1149-1090 \mathrm{~cm}^{-1}$ is assigned to the stretching vibration of $\mathrm{C}-\mathrm{O}$, and $\mathrm{C}-\mathrm{O}-\mathrm{C}$ groups in PVA. The absorption band appeared at $828 \mathrm{~cm}^{-1}$ is due to the outof-plane vibration of the $\mathrm{C}-\mathrm{H}$ group [16]. On embedding $\mathrm{Ag}$ nanoparticles in PVA, decrease in intensity of the band at 1410 and increase in the intensity of the band at 1330 . Figure. 9, represents the effect of gamma irradiation, the intensity of bands has been observed to decrease further along with the disappearance of bands in the wave number of 2852 and $1654 \mathrm{~cm}^{-1}$, with increasing gamma dose. This indicates that gamma irradiation subsequently causes the structural rearrangements in PVA chains on the embedding of Ag nanoparticles [17-18].

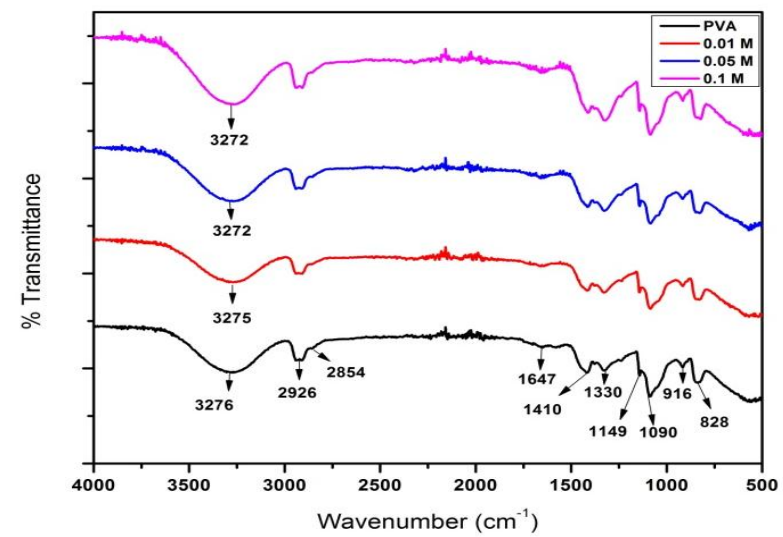

Figure 8, FTIR spectra of pure PVA and PVA/Ag nanocomposite films containing different conc. of $\mathrm{AgNO}_{3}$ 


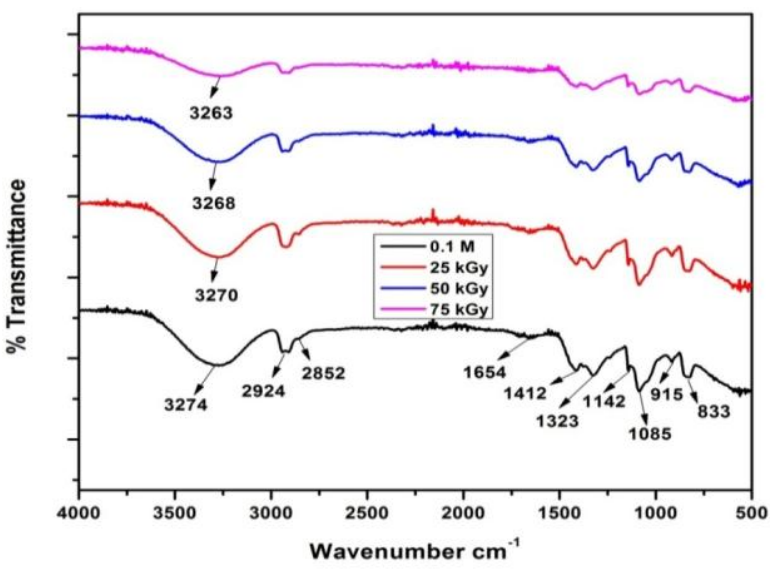

Figure 9, FTIR spectra of PVA/Ag nanocomposite films (0.1 M $\mathrm{AgNO}_{3}$,

Gamma irradiated at various irradiation doses.

\section{SEM and EDX Analysis}

The FESEM image of Ag nanoparticle dispersed in the PVA matrix. The morphology of pure PVA, unirradiated and irradiated PVA/Ag nanocomposites were examined by Field Emission Scanning Electron Microscopy (FESEM), presented in Figure. 10. It observed that pure PVA has a smooth network structure. Ag nanoparticles were homogeneously distributed within the PVA matrix film and nanoparticles displayed nearly spherical shapes [19-20]. The presence of $\mathrm{Ag}$ was confirmed by the elemental analysis Energy Dispersive X-ray Spectroscopy (EDX), presented in Figure.11.

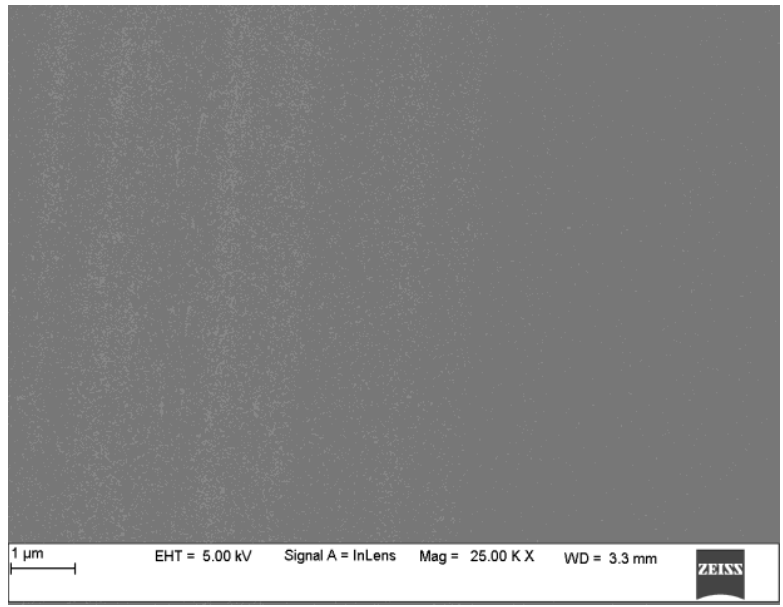

A
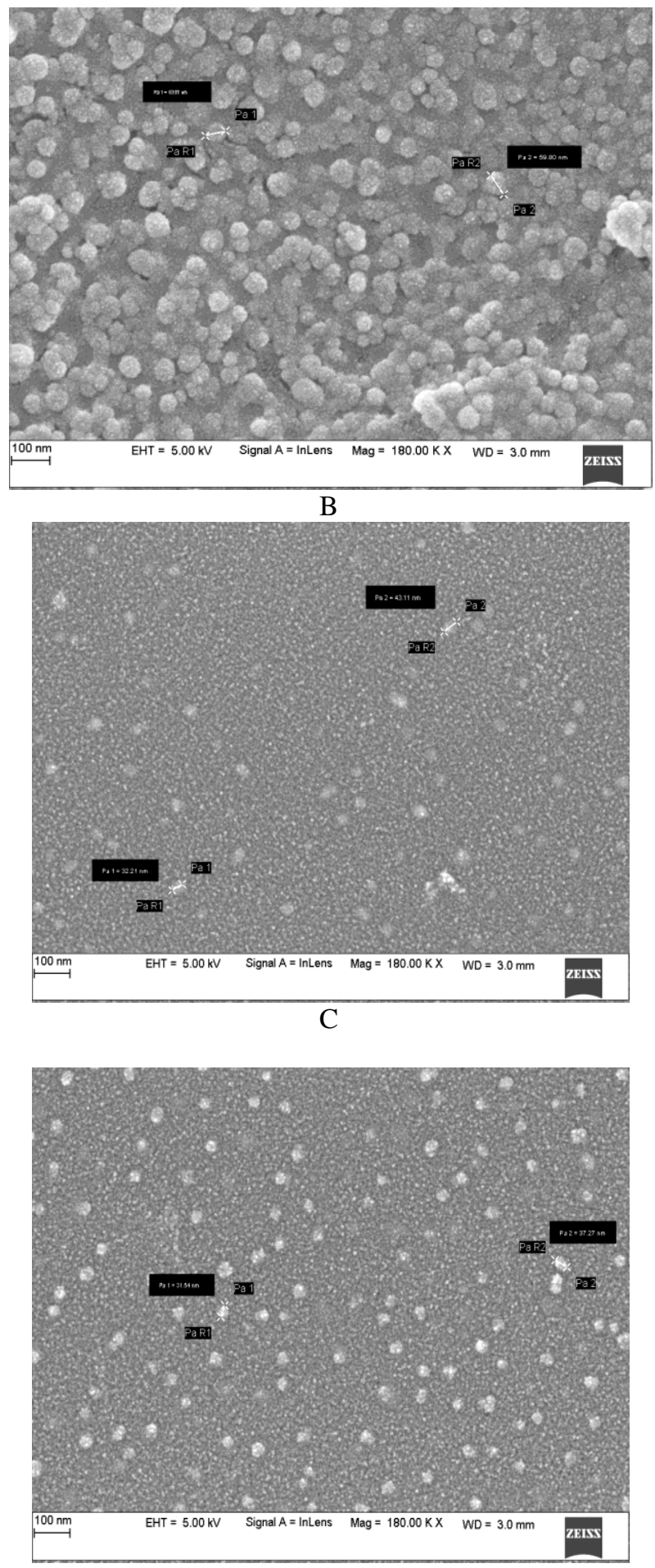

$\mathrm{D}$

Figure 10, SEM image of (a) Pure PVA (b) PVA/Ag 0.05 M (c\&d) $0.05 \mathrm{M}$ Gamma irradiated at various irradiation doses (25- $50 \mathrm{kGy})$. 


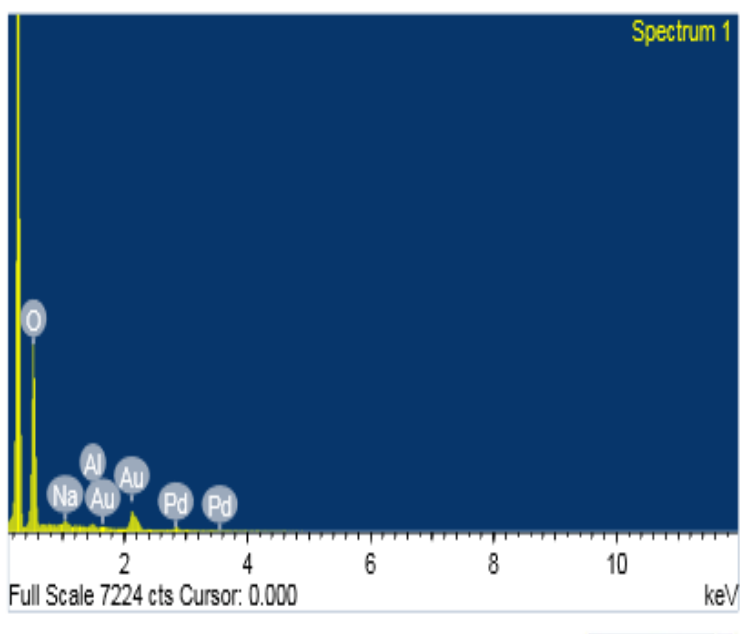

A

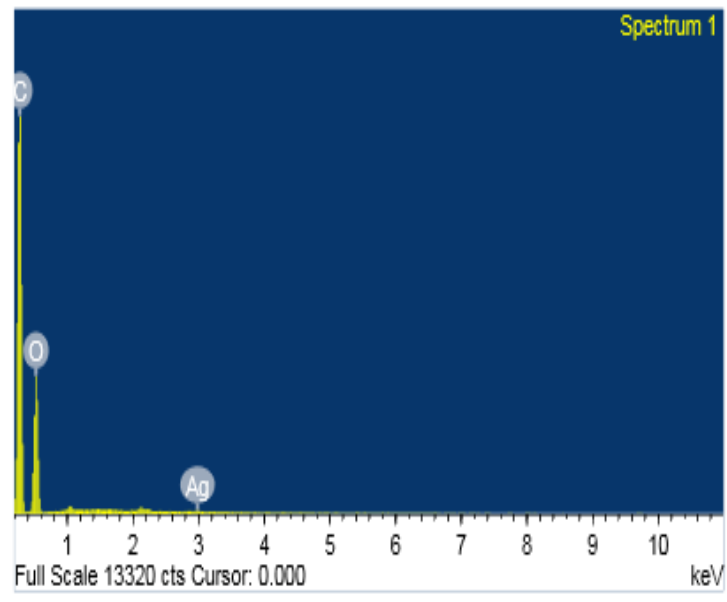

B

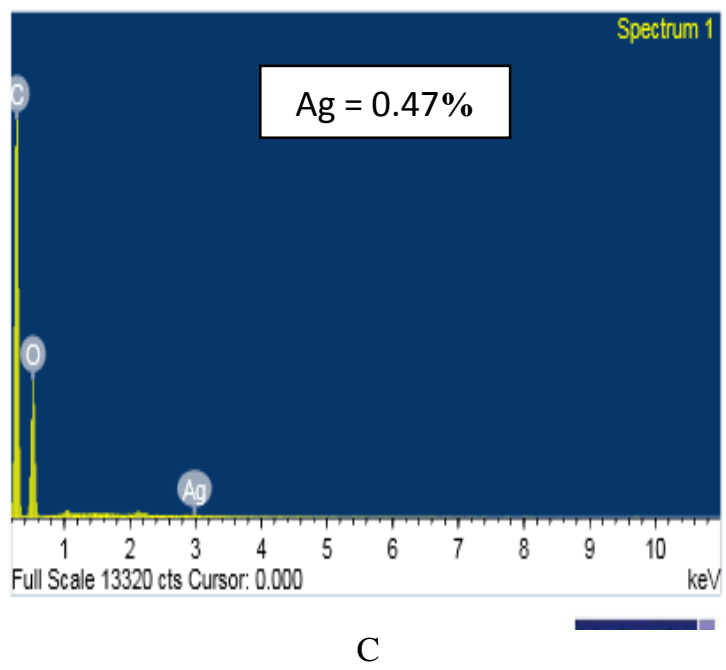

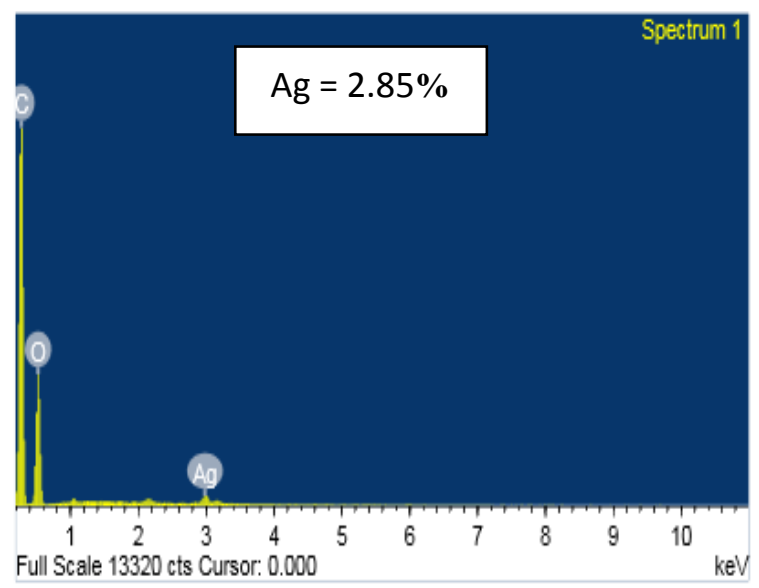

$\mathrm{D}$

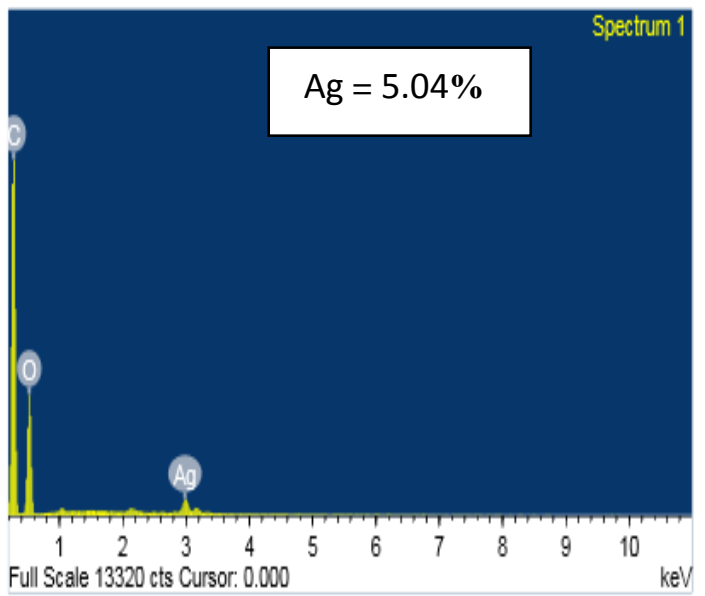

$\mathrm{E}$

Figure 11, EDX image of (a) Pure PVA and PVA/Ag nanocomposite films containing different concentrations of $\mathrm{AgNO}_{3}$ (b) $1 \times 10^{-2} \mathrm{M}$ (c) $5 \times 10^{-2} \mathrm{M}(\mathrm{d}) 1 \times 10^{-1} \mathrm{M}$

\section{E. TEM Analysis}

In order to observe the shape, size and the dispersion of $\mathrm{Ag}$ nanoparticles in PVA/Ag nanocomposite film using TEM. The images were recorded at different scales and are presented in Figure. 12. From this figure, it can be clearly seen that embedded $\mathrm{Ag}$ nanoparticles are well distributed within the PVA matrix and are nearly spherical in shape with an average diameter of $15 \pm 6 \mathrm{~nm}$. This result means that the size of the prepared particles gets smaller and the particle size distribution is improved with increasing the irradiation dose [21]. 


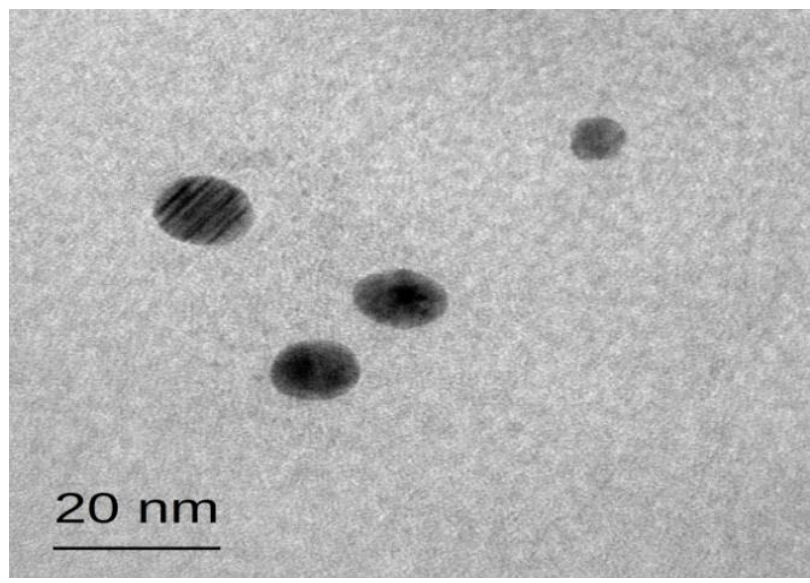

A

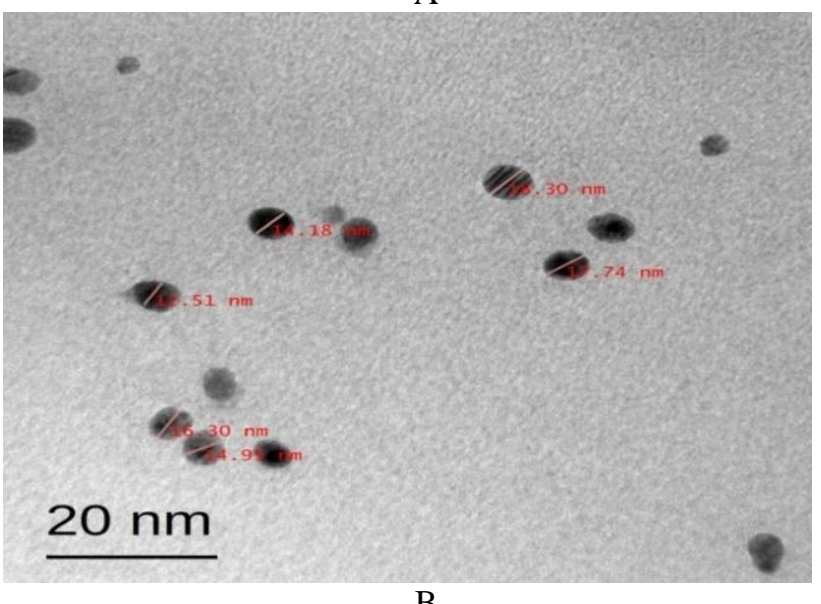

B

Figure 12, TEM image of (a)PVA/Ag $\left(5 \times 10^{-2} \mathrm{M}\right)\left(\right.$ b) $5 \times 10^{-2} \mathrm{M}$ Gamma irradiated at dose $50 \mathrm{kGy}$

\section{F. Antibacterial activities analysis}

The antibacterial properties of the nanocomposites were tested against some Gram-positive bacteria: Bacillus Subtilis, Staphylococcus aureus and Gram-negative bacteria: Escherichia coli, Klebsiella pneumoniae. A piece of sample (6 $\mathrm{mm}$ in diameter) was placed on the surface of an individual nutrient agar plate, where bacterial solutions of the microorganisms had been swabbed uniformly. After 24 h' incubation at $37^{\circ} \mathrm{C}$, the dimensions of the inhibition zones around the samples were measured in four directions, and the average values were used to calculate the circle zone area [22]. The inhibition of bacterial growth occurs in all cases where silver is present. Pure PVA does not have any antibacterial action. Table 3, shows antibacterial test results of PVA/Ag nanocomposites against bacteria determined by using the agar diffusion test. Silver nanoparticles are harmful to bacteria according to; it was found that $\mathrm{Ag}$ nanoparticles react with cell walls and finally killing them. The results confirmed that the irradiated PVA/Ag nanocomposites showed greater antibacterial effect than unirradiated nanocomposites. Figure. 13 shows the diameter increase with increasing irradiation dose. These results in a good agreement with the UV- Vis, XRD, and TEM which confirm the decreasing in the particle size with increasing the irradiation dose which leads to a good antibacterial activity [23].

Table 3. Average of inhibition zones obtained from PVA/Ag (0.05

M) nanocomposites at various

doses (0 -75 kGy) against gram-positive and gram-negative bacteria

\begin{tabular}{|c|c|c|c|c|c|}
\hline \multirow{4}{*}{$\begin{array}{c}\text { Samp } \\
\text { le } \\
(\mathrm{PVA} \\
/ \mathrm{Ag})\end{array}$} & \multirow{4}{*}{$\begin{array}{l}\text { Irradi } \\
\text { ation } \\
\text { Dose } \\
\text { (kGy) }\end{array}$} & \multicolumn{4}{|c|}{ Diameter of inhibition zone (in $\mathrm{mm}$ )* } \\
\hline & & \multicolumn{4}{|c|}{ Bacterial strains } \\
\hline & & \multicolumn{2}{|c|}{$\begin{array}{c}\text { Gram-positive } \\
\text { bacteria }\end{array}$} & \multicolumn{2}{|c|}{$\begin{array}{c}\text { Gram-negative } \\
\text { bacteria }\end{array}$} \\
\hline & & $\begin{array}{c}\text { Staphylo } \\
\text { coccus } \\
\text { aureus }\end{array}$ & $\begin{array}{c}\text { Bac } \\
\text { illus } \\
\text { subt } \\
\text { ilis }\end{array}$ & $\begin{array}{c}\text { Escher } \\
\text { ichia } \\
\text { coli }\end{array}$ & $\begin{array}{c}\text { Klebsi } \\
\text { ella } \\
\text { pneum } \\
\text { oniae }\end{array}$ \\
\hline \multirow{4}{*}{$0.05 \mathrm{M}$} & 0 & 10.0 & 9.0 & 8.5 & 11.0 \\
\hline & 25 & 12.0 & 10.5 & 9.5 & 13.5 \\
\hline & 50 & 15.0 & 13.0 & 11.0 & $\overline{14.0}$ \\
\hline & 70 & 16.0 & 15.0 & 12.0 & 16.0 \\
\hline
\end{tabular}
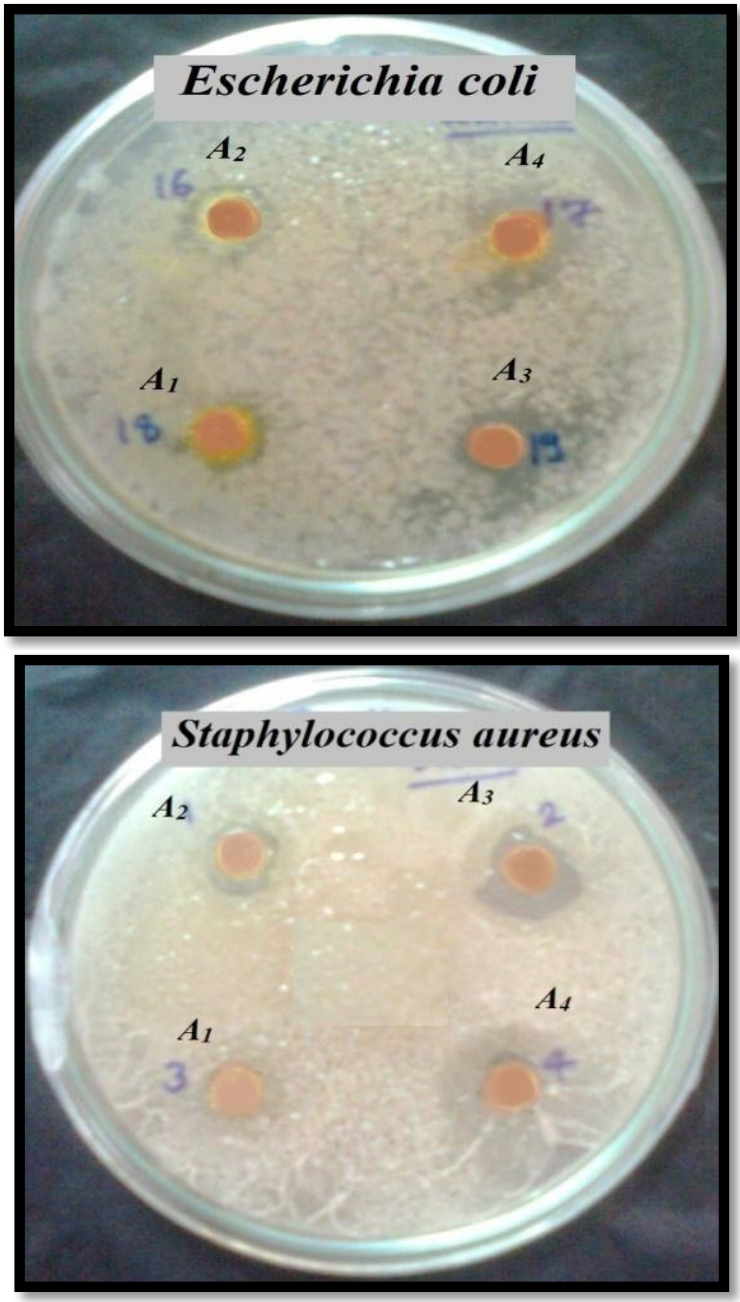

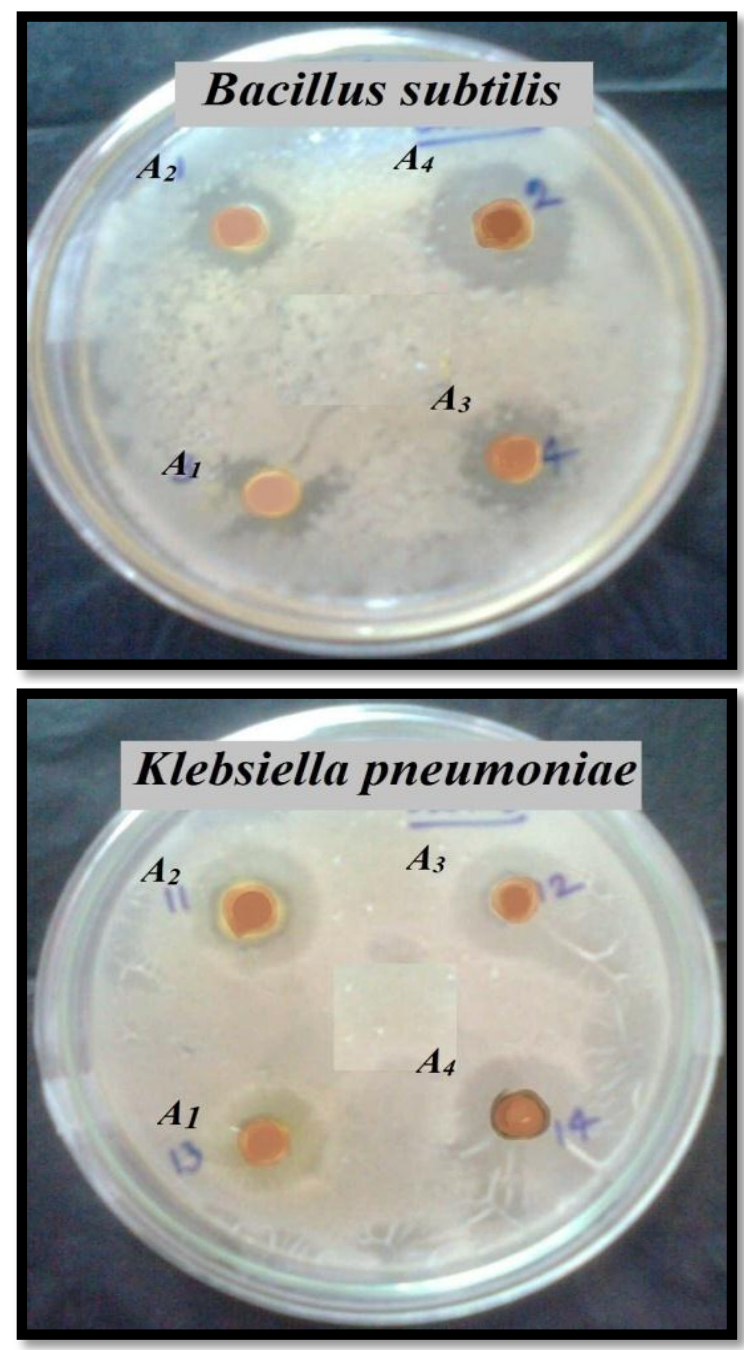

Figure 13, Zones obtained from PVA/Ag $(0.05 \mathrm{M})$ nanocomposites at various doses $\left(\left(\mathrm{A}_{1}\right) 0 \mathrm{kgy}\left(\mathrm{A}_{2}\right) 25 \mathrm{kGy}\right.$ $\left.\left(\mathrm{A}_{3}\right) 50 \mathrm{kGy}\left(\mathrm{A}_{4}\right) 75 \mathrm{kGy}\right)$ against gram-positive and gramnegative bacteria

\section{CONCLUSION}

The recent solution casting technique is a simple, costeffective and rapid form of synthesis. This method produced a spherical, monodispersed form of nanoparticles. It is well separated and no aggregation was observed. Prepared PVA/Ag samples were exposed to gamma irradiation for different doses from 25-75 kGy. When the samples were exposed to gamma radiation it shows the changes in optical and structural behavior. UV-Vis spectroscopy result shows the absorption peak is increased as the irradiation dose increased, indicating the formation of more silver nanoparticles and reduction of particle size. X-ray diffraction study confirmed the presence of Ag nanoparticles in the PVA matrix and its minimum average crystallite size was $17.01 \mathrm{~nm}$. FITR analysis reveals that silver nanoparticles attached to polymer chains through some kind of chemical conjugation. FE-SEM analysis reveals that the particles were in nano size dispersed in the PVA matrix. The presence of Ag was confirmed using EDX analysis. TEM results have shown spherical Ag nanoparticles with narrow size distribution. The antimicrobial properties of synthesized samples having the size range from $15 \mathrm{~nm}$ to $58 \mathrm{~nm}$ were effective against gram-positive and gram-negative bacteria. It also shows a good antibacterial property. This PVA/Ag nanocomposite can be used for the improvement of food application, protection product and for medical application.

\section{ACKNOWLEDGMENTS}

The authors are thankful to the Coordinator, DST-PURSE programme, Mangalore University for permitting the use of the FESEM facility and Manipal Institute of Technology (MIT) for X-Ray Diffraction analysis, Manipal University, Udupi. Sophisticated Test and Instrumentation Centre (STIC) for Transmission Electron Microscopy (TEM), Kerala.

\section{REFERENCES}

[1] Z.I. Ali, M.H. Helal, H.H. Saleh, A.F. Zikry, Y.A. Darwish, "Silver- Polymer Blend Nanocomposite", New York Science Journal, Vol.7, Issue 1, pp.84-94, 2014.

[2] N.V. Bhat, M.B. Kurup, V.A. Ba, S. Sabharwal "Effect of Gamma Irradiation on Structure and Morphology of PVA Films", Nucl. Instrum. Methods Phys. Res, Vol. 237, Issue (3-4), pp 585-592, 2005.

[3] H. Fischer, "Polymer nanocomposites: from fundamental research to specifi applications," Mater. Sci. Eng. C. Vol. 23, Issue (6-8), pp. 763-772, 2002.

[4] A. Gautam, P. Tripathy, S. Ram, "Microstructure, topology and $X$-ray diffraction in Ag-metal reinforced polymer of polyvinyl alcohol of thin laminates", J. Mater. Sci. Vol. 41, Issue 10, pp. 3007- 3016, 2006.

[5] M.A.A. Omer, E. Saion, G.M.E. Mar-elnabi, E.A.A Balla, Kh.M Dahlan, Y.M Yousif, "Gamma Radiation Synthesis and Characterization of Polyvinyl Alcohol/ Silver Nano Composites Film”, J.Sc. Tech. Vol. 12, Issue 1, pp. 104-110, 2011.

[6] M.A.A. Omer, E. Saion, G.M.E. Mar-elnabi, E.A.A Balla, Kh.M Dahlan, Y.M Yousif, "Gamma Radiation Synthesis and Characterization of Polyvinyl Alcohol/ Silver Nano Composites Film”, J.Sc. Tech. Vol. 12, Issue 1, pp. 104-110, 2011.

[7] J. Puišo, I. Prosyčevas, A. Guobienè, S. Tamulevičius, "Plasmonic properties of silver in polymer", Mater. Sci. Eng. B, Vol. 149, Issue 3, pp. 230-236, 2008.

[8] S.H Wang, W. Xu, H. Si, X. Tao, S. Lou, Z. Du, L.S. Li, "Synthesis and assembly of monodisperse spherical $\mathrm{Cu}_{2} \mathrm{~S}$ nanocrystals", J. Colloid Interface Sci. Vol. 330, Issue 2, pp. 483-487, 2009.

[9] W. H. Eisa, Y. K. Abdel-Moneam, Y. Shaaban, Atef A. AbdelFattah, A. M. Abou Zeid, "Gamma-irradiation assisted seeded growth of Ag nanoparticles within PVA matrix", Mater. Chem. Phys. Vol. 128, Issue (1-2), pp. 109-113, 2011.

[10] D.D. Evanoff Jr, G. Chumanov, "Size-controlled synthesis of nanoparticles .1. "Silver-only" aqueous suspensions via 
hydrogen reduction", J. Phys. Chem. Vol. 108, Issue 37, pp. 13948-13956, 2004.

[11] P.C. Rishi, M. Suman, A.K. Tomar, K. Shyam, " $\gamma$-Irradiated PVA/Ag nanocomposite films: Materials for optical applications", J. Alloy. Compd. Vol. 538, pp. 212-219, 2012.

[12] Q.L. Feng, J. Wu, G.Q. Chen, F.Z. Cui, T.N. Kim, J.O. Kim, “A mechanistic study of the antibacterial effect of silver ions on Escherichia coli and Staphylococcus aureus", J. Biomed. Mater. Res. B, Vol. 52, Issue 4, pp. 662-668, 2008.

[13] H. H. Saleh, D.E. El-Hadedy, G.A. Meligi, T.A. Afify, "Synthesis, Characterization and Antibacterial Activity of Ag/PVA Nanocomposite”, J. Sci. Res. Adv. Vol. 5, Issue 1, pp. 151-160, 2013.

[14] Z.I. Ali, H.H. Saleh, T.A. Afify, "Optical, Structural and Catalytic Evaluation of Gamma-Irradiation Synthesized Ag/PVA Nanocomposite Films", International Journal of Engineering Research \& Technology, Vol. 3, Issue 9, pp. 1527-1538, 2014.

[15] K. Chamakura, R. Perez-Ballestero, Z.P. Luo, S. Bashir, J. Liu, "Comparison of bactericidal activities of Ag-NPs with common chemical disinfectants", Colloids Surf. B, Vol. 84, Issue 1, pp. 88-96, 2011.

[16] L.S. Birks, H. Friedman, "Particle Size Determination from $X$ Ray Line Broadening”, J. Appl. Phys, Vol. 17, Issue 8, pp. 687692, 1946.

[17] Z.H. Mbhele, M.G. Salemane, C.G.C.E. Van Sittert, J.M. Nedeljkovic, V. Djokovic, Luyt, "Fabrication and Characterisation of Silver-PolyvinylAlcohol Nanocomposites", Chem. Mater. Vol. 15, Issue 26, pp. 5019-5024, 2003.

[18] O. Pravakar, T. Siddaiah , N.O. Gopal, Ch. Ramu, "Structural, Optical and Electrical conductivity Studies of Mn2+ Ions Doped PVA/MAA: EA Polymer Blend Films" International Journal of Scientific Research in Physics and Applied Sciences, Vol. 6, Issue 6, pp. 80-87, 2018.

[19] M. Ghanipour, D. Dorranian, "Effect of Ag-Nanoparticles Doped in Polyvinyl Alcohol on the Structural and Optical Properties of PVA Films", J. Nanomater. Vol. 2013, pp. 1-10, 2013.

[20] O. Pravakar, T. Siddaiah , N.O. Gopal, Ch. Ramu, "Structural, Optical and Electrical conductivity Studies of Mn2+ Ions Doped PVA/MAA: EA Polymer Blend Films" International Journal of Scientific Research in Physics and Applied Sciences, Vol. 6, Issue 6, pp. 80-87, 2018.

[21] W. H. Eisa, Y. K. Abdel-Moneam, Y. Shaaban, Atef A. AbdelFattah, A. M. Abou Zeid, "Gamma-irradiation assisted seeded growth of Ag nanoparticles within PVA matrix", Mater. Chem. Phys. Vol. 128, Issue (1-2), pp. 109-113, 2011.

[22] H.K. Chitte, N.V. Bhat, N.S. Karmakar, D.C. Kothari, G.N. Shinde, "Synthesis and characterisation of polymeric composites embedded with silver nanoparticles", Worl. J. Nano. Eng. Vol.2, Issue 1, pp. 19-24, 2012.

[23] T. Galya, V. Sedlarık, I. Kuritka, R. Novotny, J. Sedlari kova, P. Saha, "Antibacterial Poly(vinyl Alcohol) Film Containing Silver Nanoparticles: Preparation and Characterization”, J. Appl. Polym. Sci, Vol. 110, Issue 5, pp. 3178-3185, 2008.

\section{Author's Profiles}

Pushpanjali M.G presently pursuing $\mathrm{Ph} . \mathrm{D}$ degree in University Science Instrumentation Centre (USIC), Department of physics from Mangalore University, Mangalore, Karnataka, India. She received her B.Sc degree from Mahatma Gandhi Memorial College, udupi, under Mangalore University in 2011, Karnataka, India and her M.Sc. degree from Mangalore University in 2013.

Prof. H.M Somashekarappa received $\mathrm{Ph} . \mathrm{D}$ in 1994 from Mangalore University, Karnataka, India. He is working as Professor and Head of University Science Instrumentation Centre (USIC) and also Centre-inCharge of 'Centre for Application of Radioisotopes and Radiation Technology' (CARRT), Mangalore University. His main research work focus on Applications of Radioisotopes and Radiation Technology, Environmental Radioactivity and Radiation Dosimetry, Radiation Scattering Studies, Nucleonic Gauges, Radioactive Aerosols. $\mathrm{He}$ has completed 3 projects and 4 ongoing. $\mathrm{He}$ has organised more than 9 Seminars/Workshops/Training Programs. 